\title{
O Papel da Administração na Aliança Para o Progresso
}

Os Ministros das Relações Exteriores dos paises da América - menos o do Canadá - reunidos em Punta del Este, em agôsto de 1961, elaboraram e aprovaram os documentos institucionais da Aliança para o Progresso. Como se sabe, esta é a denominação dinâmica adotada pelo atual Presidente dos Estados Unidos para batizar a nova politica desenwolvimentista interamericana.

Ao lado da Carta de Punta del Este, os documentos mais importantes, pelo humanismo das idéias e envergadura dos propósitos, surgidos daquela reunião epocal, são as "Resoluções Anexas A-1 e A-2".

A primeira configura a batalha continental que os paises da América se comprometeram a ferir, no decênio 1961-1970, contra o analfabetismo. Trata-se do Plano Decenal de Educação da Aliança para o Progresso, que será executado em todos os paises da América Latina, mediante cooperação técnica e financeira internacional. O objetivo principal dêste plano é proporcionar, no minimo, seis anos de educação primária gratuita e obrigatória a tôda a população em idade escolar do Continente, o que pressupõe um aumento de aproximadamente 20 milhões de matriculas nas escolas primárias.

A "Resolução Anexa A-2" contém o Plano Decenal de Saúde Pública da Aliança para o Progresso. O objetivo principal dêste é aumentar de cinco anos, no minimo, a expectativa de vida do latino-americano ao nascer, o que pressupõe aumento e melhoria dos serviços de água e esgôto, redução dos indices atuais de mortalidade infantil, erradicação da malária e variola, e várias outras medidas de proteção à saúde e ao bem-estar da população. 
Concebida com visivel pragmatismo, a Carta de Punta del Este enumera os objetivos, indica os processos e arrola os meios de ação. Inclui, entre os últimos, a capacidade administrativa, apontando a como fator básico, indispensável e universal do desenvolvimento.

No título II, por exemplo, que trata do desenvolvimento econômico e social, figuram entre os requisitos básicos e medidas de ação imediata, a curto e a longo prazo, "programas tendentes a melhorar os serviços públicos". No Apêndice, que enumera os elementos constituintes dos programas de desenvolvimento econômico nacional, figura novamente "o mecanismo da administração pública". Em suma, todo o texto da Carta de Punta del Este, inclusive a "Declaração aos Povos da América", acentua e realça o papel da boa administração como condição essencial do desenvolvimento.

A Aliança para o Progresso veio consagrar, assim, definitivamente, velha tese brasileira, sustentada com vigor nas discussões internacionais desde 1948, de que a capacidade executiva representa a mais eficaz arma de combate ao subdesenvolvimento.

Não se pode considerar revolucionária, nem mesmo novidadosa, a posição dos elaboradores da Carta de Punta del Este relativamente ao fator administração. Mas cumpre reconhecer-lhe a virtude do realismo. Veio infirmar a crença falaz, que orientou durante anos as atividades de assistência técnica das organizações internacionais de que o subdesenvolvimento se erradicava mediante simples importação de capitais e equipamento pesado.

Conforta-nos verificar que os governos dos paises americanos, no momento em que lançam as bases de seus programas de desenvolvimento econômico e social de envergadura continental, destinados a redimir os povos da. América Latina dos grilhões, das privações e das humilhações do analfabetismo, do pauperismo e das precárias condições de vida, reconhecem e proclamam de público a essenciabilidade da boa administração nos planos de combate ao subdesenvolvimento. 
O Departamento Administrativo do Serviço Público, guardião do sistema do mérito no Brasil e, ao mesmo tempo, centro de treinamento dos servidores do Estado nas modernas técnicas administrativas, e de difusão, através do livro, do folheto e do periódico, de informações e doutrinas sôbre a ciência da administração, vive e pratica a tese agora perfilhada pela Aliança para o Progresso.

Nossa pregação e nossa obra outra coisa não têm sido senão a pregação e a obra da boa administração pública. Inclusive a idéia do planejamento global, condição indispensável estabelecida e reconhecida na Carta de Punta del Este como fator do desenvolvimento econômico e social, o D.A.S.P. vem difundindo e prestigiando desde a sua criação, em 1939.

$\mathrm{Na}$ Aliança para o Progresso, como na história do D.A.S.P., o fator supremo de progresso não é o financiamento: é a boa administração. 